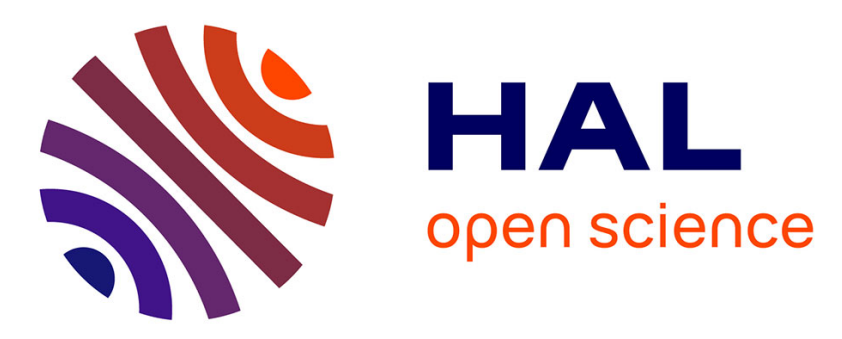

\title{
Recolonization and recovery dynamics of the macrozoobenthos after sand extraction in relict sand bottoms of the Northern Adriatic Sea
}

R. Simonini, I. Ansaloni, P. Bonini, V. Grandi, F. Graziosi, M. Iotti, G. Massamba-N'Siala, M. Mauri, G. Montanari, M. Preti, et al.

\section{To cite this version:}

R. Simonini, I. Ansaloni, P. Bonini, V. Grandi, F. Graziosi, et al.. Recolonization and recovery dynamics of the macrozoobenthos after sand extraction in relict sand bottoms of the Northern Adriatic Sea. Marine Environmental Research, 2007, 64 (5), pp.574. 10.1016/j.marenvres.2007.06.002 . hal00501918

\section{HAL Id: hal-00501918 \\ https://hal.science/hal-00501918}

Submitted on 13 Jul 2010

HAL is a multi-disciplinary open access archive for the deposit and dissemination of scientific research documents, whether they are published or not. The documents may come from teaching and research institutions in France or abroad, or from public or private research centers.
L'archive ouverte pluridisciplinaire HAL, est destinée au dépôt et à la diffusion de documents scientifiques de niveau recherche, publiés ou non, émanant des établissements d'enseignement et de recherche français ou étrangers, des laboratoires publics ou privés. 


\section{Accepted Manuscript}

Recolonization and recovery dynamics of the macrozoobenthos after sand extraction in relict sand bottoms of the Northern Adriatic Sea

R. Simonini, I. Ansaloni, P. Bonini, V. Grandi, F. Graziosi, M. Iotti, G. Massamba-N'Siala, M. Mauri, G. Montanari, M. Preti, N. De Nigris, D. Prevedelli

PII: S0141-1136(07)00073-6

DOI: 10.1016/j.marenvres.2007.06.002

Reference: MERE 3126

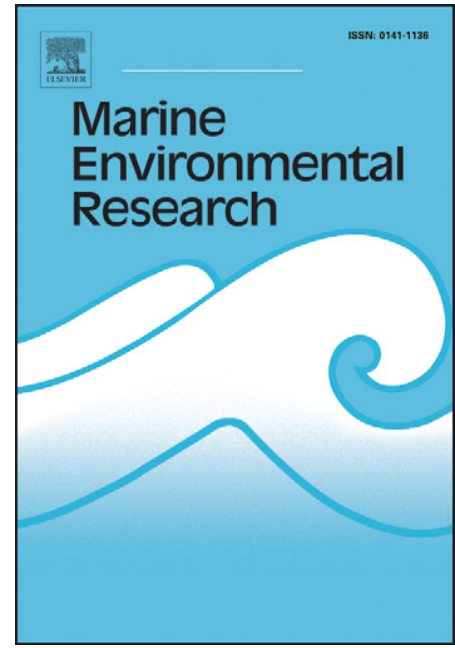

To appear in:

\section{Marine Environmental Research}

Received Date:

16 June 2006

Revised Date:

30 May 2007

Accepted Date:

11 June 2007

Please cite this article as: Simonini, R., Ansaloni, I., Bonini, P., Grandi, V., Graziosi, F., Iotti, M., MassambaN'Siala, G., Mauri, M., Montanari, G., Preti, M., De Nigris, N., Prevedelli, D., Recolonization and recovery dynamics of the macrozoobenthos after sand extraction in relict sand bottoms of the Northern Adriatic Sea, Marine Environmental Research (2007), doi: 10.1016/j.marenvres.2007.06.002

This is a PDF file of an unedited manuscript that has been accepted for publication. As a service to our customers we are providing this early version of the manuscript. The manuscript will undergo copyediting, typesetting, and review of the resulting proof before it is published in its final form. Please note that during the production process errors may be discovered which could affect the content, and all legal disclaimers that apply to the journal pertain. 
Recolonization and recovery dynamics of the macrozoobenthos after sand extraction in relict sand bottoms of the Northern Adriatic Sea.

R. Simonini ${ }^{a^{*}}$, I. Ansaloni ${ }^{\text {a }}$, P. Bonini ${ }^{\text {a }}$, V. Grandi a , F. Graziosi ${ }^{\text {a }}$, M. Iotti ${ }^{\text {a }}$, G. Massamba-N'Siala ${ }^{a}$, M. Mauri ${ }^{a}$, G. Montanari ${ }^{b}$, M. Preti ${ }^{\text {c }}$, N. De Nigris ${ }^{\text {c }}$, D. Prevedelli $^{\mathrm{a}}$

a Dipartimento di Biologia Animale, Università degli studi di Modena e Reggio Emilia, via Campi 213/D, 41100 Modena, Italy

${ }^{\mathrm{b}}$ ARPA Emilia-Romagna, Struttura Oceanografica Daphne, via Vespucci, Cesenatico (FC), Italy

${ }^{\mathrm{c}}$ ARPA Emilia-Romagna, Ingegneria Ambientale, Vicolo Carega 10, Bologna, Italy

${ }^{*}$ Corresponding author

Simonini Roberto

Dipartimento di Biologia Animale, Università degli Studi di Modena e Reggio Emilia, Via Campi 213/D, 41100 Modena, Italy

Tel: +3959-2055562; fax: +3959-2055548

E-mail address: simonini.roberto@unimore.it 


\begin{abstract}
The long-term effects of sand extraction on macrozoobenthic communities were investigated in an offshore area in the Northern Adriatic Sea characterised by relict sands formed during the last Adriatic post-glacial transgression. Surveys were carried out before, during and 1, 6, 12, 18, 24 and 30 months after extraction at three impacted and seven reference stations. The operations did not influence the physical characteristics of the sediment, but they caused almost complete defaunation at dredged sites. Univariate and multivariate analyses highlighted that the macrozoobenthic community responses to the dredging operations were 1) a rapid initial recolonisation phase by the dominant taxa present before dredging, which took place 6-12 months after sand extraction; 2) a slower recovery phase, that ended 30 months after the operations, when the composition and structure of the communities were similar in the dredged and reference areas. This pattern of recolonisationrecovery fits well with the commonly encountered scenario where the substratum merely remains unchanged after marine aggregate extraction.
\end{abstract}

Keywords: Environmental impact; Dredging; Sand extraction; Benthos; Recolonisation; Recovery; Northern Adriatic Sea; Relict sands 


\section{Introduction}

The impact of marine sand extraction on the characteristics of the seabed and the changes in benthic fauna have been widely investigated (Newell, Seiderer, \& Hitchcock, 1998; Sardà, Pinedo, Gremare, \& Taboada, 2000; Van Dalfsen, Essink, Toxvig Madsen, Birklund, Romero, \& Manzanera, 2000). The dredging operations may influence the physical and biological characteristics of the impacted areas both directly, through removal, smothering and damage caused by the dredge head, and indirectly: surface and bottom plumes, changes in plankton bloom seasons, the release of nutrients and chemicals, as well as sound, can affect both the sea bottom and the water column in the immediate area around the dredging site (Boyd, Limpenny, Rees, \& Cooper, 2005; Newell et al., 1998; Van Dalfsen et al., 2000).

Most studies concerning the impacts of sand dredging on macrozoobenthos were performed in shallow, dynamic sandy bottoms. In these cases, the recovery of the benthic assemblages appeared to be linked to the alterations in the seabed, in terms of grain size, organic content and morphology induced by sand extraction. Major alterations in the sediment and grain size characteristics over a long period favoured the settlement of benthic communities that were different in composition and structure from the pre-operational ones and this difference could be maintained for a long time (Boyd, Limpenny, Rees, Cooper, \& Campbell, 2003; Boyd et al., 2005; Van der Veer, Bergman, \& Beukema, 1985). In contrast, when there was minimal variation in the seabed characteristics, benthic communities recovered within a few years in terms of biodiversity and biomass (Boyd et al., 2003; Kenny \& Rees, 1994, 
1996; Kenny, Rees, Greening, \& Campbell, 1998; Robinson, Newell, Seiderer, \& Simpson, 2005; Van Dalfsen \& Essink, 1997).

The largest nourishment operation in the Mediterranean Sea took place in 2002, when approximately $800,000 \mathrm{~m}^{3}$ of sand were dredged from off-shore relict sand deposits in the Northern Adriatic Sea. These were destined for the nourishment of several beaches along the Emilia-Romagna coast (Italy) (Simonini et al., 2005). Besides the geographical location, this operation was unusual because the seabed of the area 1) did not show active sedimentation, 2) was primarily composed of relict sand, 3) was far from the coast $(55 \mathrm{~km})$ and 4) at a greater depth $(40-42 \mathrm{~m})$ compared with the other previous dredging operations, where the maximum dredging depth was usually around 30 metres (North Sea Foundation, 2005).

The analysis of the short-term impacts of sand extraction on sediment and macrozoobenthos during the first 12 months after dredging, highlighted that the activities did not significantly influence the granulometry and the total organic carbon content (\% TOC) of the substratum, but caused almost complete defaunation at the dredging stations. Yet, at the end of this survey period, the recolonisation of the communities at the impacted stations was at an advanced stage (Simonini et al., 2005).

In the present paper, we analysed the impact of relict sand extraction on benthic communities and the degree of recolonisation of macrobenthos at the end of the monitoring program, up to 30 months after the completion of the dredging. The aim was to establish the recolonization-recovery state of the macrozoobenthos and obtain a reference model for the effects of sand extraction on relict sand bottoms. 


\section{Materials and methods}

\subsection{Study area and sampling}

The dredged area is located approximately $55 \mathrm{Km}$ off the coast of Ravenna, in an area characterized by the occurrence of relict offshore sandy deposits (Fig. 1; Preti, 2000). These deposits, mainly composed of sand and coarse detritus, are the remains of coastal structures that were formed during the last Adriatic marine transgression. This area is outside the main current circuit of the Northern Adriatic, and as a result is characterized by a limited amount of sedimentation of fine material during the summer period that become re-suspended and dispersed during the winter (Preti, 2000, 2002; Simonini et al., 2005). The tidal excursion is negligible and the currents are weak and with variable direction. In fact, the main factors that affect the sediment transport and re-suspension in the area are the storms driven by the NE and SE winds (Bora and Scirocco) that frequently occur in the Northern Adriatic Sea from December to late March and probably lead to significant sediment re-suspension (Matteucci and Frascari, 1997; Wang, 2002). Water temperature in the bottom showed marked seasonal variation ranging from $8^{\circ} \mathrm{C}$ in February to $26^{\circ} \mathrm{C}$ in August (Montanari \& Pinardi, 2006).

The dredging operations took place in April-May 2002. The monitoring activities started in March 2001 and ended in December 2004. Eight sampling surveys were carried out: March 2001 (before extraction [B.-Ex.]), April 2002 (during extraction [Ex.]), June 2002 (1 month after extraction [A.-Ex. 1]), December 2002 (6 months after extraction [A.-Ex. 6]), June 2003 (12 months after extraction [A.-Ex. 12]), 
December 2003 (18 months after extraction [A.-Ex. 18]), June 2004 (24 months after extraction [A.-Ex. 24]) and December 2004 (30 months after extraction [A.-Ex. 30]). Because of the lack of information on the effects of sand extraction in the Northern Adriatic Sea, most of the efforts were devoted to the after-dredging surveys (7 survey), in order to analyze the major recolonization-recovery patterns of the macrozoobenthos, as opposed to the characterization on the temporal variability of community before dredging (1 survey).

Surveys and sampling activities were performed with the oceanographic M/S "Daphne II" of ARPA (Regional Agency for Prevention and the Environment of Emilia-Romagna). The sampling design provided for samples at three impacted stations within the extraction area and at seven reference stations outside it. The stations were positioned along two transects perpendicular to and intersecting each other in the centre of the dredging zone (Fig. 1). The reference sites were chosen at large enough distances so as not to be affected by the extraction activity and deposition of suspended sediment. The direction and extension of the plume during the extraction were monitored by ARPA Daphne. During the extraction the currents were weak and variable and the plume never reach the inner reference stations. Multibeam profile, Side Scan Sonar and video camera images were used to measure the depth of the excavation pits and holes.

The sampling for macrozoobenthos was carried out using a van Veen grab with a surface area of $1250 \mathrm{~cm}^{2}$ and sampling volume of $24 \mathrm{dm}^{3}$. Three replicates were collected at each station. For each station, analyses for sediment granulometry and \% TOC were also performed (ICRAM, 2001). 
The samples for macrozoobenthos analysis were sieved (mesh size $0.5 \mathrm{~mm}$ ) and the retained material was preserved in $4 \% \mathrm{CaCO}_{3}$ buffered formalin in seawater.

\subsection{Data analysis}

The samples and the data were treated and analysed using the same techniques described in Simonini et al. (2005). The residual material obtained from the sample sieving was sorted in the laboratory and the macrofauna was preserved in $70 \%$ ethylic alcohol. Most of the organisms were identified to species level. Data from each sampling station were obtained from the sum of their respective replicates.

The data collected during the different surveys were integrated by obtaining a total matrix of the abundances and the main ecological indices (number of species/taxa, abundance and Shannon-Wiener diversity) were calculated.

Multivariate analyses were performed with original (untrasformed) and $4^{\text {th }}$ root transformed abundance data in order to analyze the patterns of variation of benthic assemblages in terms of numerically dominant species and species composition. Outputs from non-metric Multidimensional Scaling (nMDS) ordination models of the Bray-Curtis similarity matrix were obtained for all the stations/surveys. Differences among the extraction and reference stations during different surveys were tested using a two-way crossed ANOSIM (ANalysis Of SIMilarity) randomisation-permutation test. One-way ANOSIM was performed to compare a posteriori the extraction area stations with the reference stations, and the reference stations of the various surveys. The species making the greatest contribution to dissimilarity among the impacted and reference stations for the different surveys were investigated using the SIMilarity 
PERcentage breakdown procedure (SIMPER). The analyses were carried out using PRIMER V5 software (Clarke \& Warwick, 2001).

\section{Results}

\subsection{Sediment characteristics}

Both the reference and impacted sites did not differ for the sediment characteristics during the whole examined period. In all the samples analysed the percentage of sand varied from $85 \%$ to $98 \%$, with the prevalence of fine sands $(250-125 \mu \mathrm{m})$, and the \% TOC was low $(0.3-0.8 \%)$. The recorded sailing tracks of the dredger and the bathymetric changes in the sea bed after sand extraction revealed that the operations were carried out mainly in the southern and central parts of the dredged area, corresponding to sampling stations 4 and 3 (Fig. 1,2). During the extraction period the currents were weak and directed toward S9, but the dredged-sediment plumes were confined to within $1 \mathrm{~km}$ of the sand extraction area. The reconstruction of the bottom profile based on multi-beam data collected immediately after the extraction showed that pits with a depth of $1.5 \mathrm{~m}$ had formed on the seabed of the impacted area, due to the extraction activities (Fig. 3). The surface area and the depth of these "holes" tended to decrease over time: their mean depth was about $0.30 \mathrm{~m}$ in the the A.-Ex. 24 months surveys (Fig. 3).

\subsection{Taxonomic analysis}

The taxonomic analysis of the samples collected during the eight surveys led to the identification of about 42000 individuals, belonging to 183 taxa and distributed 
among 12 phyla (in order of abundance: annelids, arthropods, molluscs, nemertines, echinoderms, sipunculids, phoronids, poripherans, cnidarians, echiurians, chordates and hemichordates). The polychaetous annelids were the most abundant group (43\% of the taxa, $59 \%$ of the individuals), followed by the molluscs (mainly bivalves and gastropods, $24 \%$ of the taxa and $4 \%$ of the individuals), the arthropods (mostly crustaceans, $18 \%$ of the taxa and $33 \%$ of the individuals) and the echinoderms (echinoids, stellaroids and ophiuroids, $9 \%$ of the taxa and $2 \%$ of the individuals). All the other phyla together represented $7 \%$ of the taxa, but only $1 \%$ of the individuals. The species were characteristic of offshore sandy-muddy bottoms. No mass settlement of opportunistic species or species typical of disturbed bottoms was observed in the impacted areas. The list of the taxa found during the whole monitoring program was reported in Appendix 1.

\subsection{Abundance data analyses}

The multivariate analyses performed on original and $4^{\text {th }}$ root transformed data highlighted that the sand extraction affected the macrozoobenthic communities of the impacted stations during and after sand extraction, both in terms of species composition and of numerically dominant species (ANOSIM, Table 1).

The MDS ordination plots of the untransformed and $4^{\text {th }}$ transformed data relating to each station and sampling date (Fig. 4a, b) showed the stations 3 and 4 of the Ex. and A.-Ex. 1 surveys to be segregated towards one side, while the reference and the dredging station of the last three A.-Ex. Surveys (A.-Ex. 18, A.-Ex. 24 and A.-Ex. 30 surveys) were grouped on the other side, very close to each other. Between these two 
extremes, there were the points indicative of stations 2-4 of the A.-Ex. 6 and A.-Ex. 12 months surveys) (Fig. 4a, b). The MDS sub-plot of the impacted station from the different surveys (Fig. 4c, d) showed the same patterns as the whole plot.

In the Ex and A.-Ex. 1 survey, the average dissimilarities of impacted station with respect to the reference station and B-Ex Imp. stations were very high and significant (80-90\% with untransformed data, $70-75 \%$ with $4^{\text {th }}$ root transformed data) (Table 23). The stations 3 and 4 of the Ex. and A.-Ex. 1 surveys underwent almost complete defaunation after the sand extraction, evidenced by the drastic reduction in the number of taxa, abundances and Shannon-Wiener diversity with respect to references stations (Table 2; Fig. 5). Station 2, located in the northern part of the extraction area, was subject to a lower impact and showed a smaller reduction in the number of taxa and abundances than station 3 and 4 (Table 4; Fig. 5).

The intermediate position of the stations 2-4 of the A.-Ex. 6 and A.-Ex. 12 surveys in the MDS plots of Fig. 3a-d suggested that recolonisation was taking place at these stations. In fact the average dissimilarity of impacted station in the Ex and A.-Ex. 1 survey, with respect to B-Ex Imp. stations was 63-83\% (untransformed data) and 45$66 \%\left(4^{\text {th }}\right.$ root transformed data) (Table $\left.2-3\right)$. Moreover, the dredged stations showed abundances that were about $40-50 \%$ lower than the reference stations, whereas during the A.-Ex. 1 survey the mean difference was about $90 \%$. In addition, the number of taxa discovered at the extraction area stations was $60-70 \%$ of that observed at the reference stations, whereas during the surveys carried out during and 1 month after extraction this percentage was only $26 \%$ (Table 4; Fig. 5). 
Although the reference sites of each survey are tightly grouped on one side of the global MDS plots (Fig. 4a, b), the MDS subplots of the reference station from the different surveys highlighted the great temporal variability of the community, throughout the eight surveys both in term of species composition and, overall, in term of numerically dominant species (Fig. 4 e-f). In particular, the MDS plots showed the reference station of the A-Ex 12 survey segregated separately and more dispersed than the others, due to the lower abundances and number of taxa found (Table 4).

With the exception of the A-Ex 12 survey, the dissimilarities among surveys were lower than could be ascribed to the impact of the extraction activity, ranging from 25 to $42 \%$ ( $4^{\text {th }}$ root transformed data) and from 33 to $62 \%$ (untransformed data). Yet the results of the one-way ANOSIM tests between the references station of the eight surveys showed that the communities varied from one survey to another (Table 2, 3), probably because the high within-groups similarities $(60-70 \%$ with untransformed data, $70-80 \%$ with $4^{\text {th }}$ root transformed data). Most of the dissimilarities among the reference stations of different surveys were due to variations in the abundances of some of the more highly represented and/or characteristic species, and to the occurrence of low-density, rare species that characterize one or more surveys (SIMPER, Simonini et al, 2005). In fact only about the 50\%-60\% of the species found throughout the whole investigation were common to the reference station of all the surveys but these species represented $90-95 \%$ of the total abundance.

The high R-values suggested that the community of the B-Ex. Imp. station and the impacted station from the other survey are different from one survey to another, despite their dissimilarity decrease over time after the dredging (Table 2, 3). The 
SIMPER analysis performed on the $4^{\text {th }}$ root-transformed data from the B-Ex or the AEx 30 impacted stations has emphasized the role of some rare species with very low density (Appendix 2). The same analysis performed without data transformation highlighted that the differences in the communities of the impacted station before and 30 month after dredging were mostly due to variations in the abundances of the more highly represented and characteristic species of the relict sands, such as the polychaetes Aricidea claudiae, Spiophanes kroyeri kroyeri, Monticellina dorsobranchialis and Jasmineira elegans, and the crustaceans Ampelisca diadema and Apseudes latreilli (Appendix 2). As observed for the reference station of the different survey, the communities of the impacted station before and 30 month after sand extraction have a number (52\%) of species in common. These species contributed to the $89 \%$ and the $91 \%$ of the total abundances of the B-Ex impacted station and the A-Ex. 30 impacted station.

\section{Discussion}

Despite the extraction depth and the considerable volume of sand removed, negligible change in sediment structure were observed at the relict sand extraction sites in the Northern Adriatic Sea. The deep depressions created by the extraction have gradually been levelled out by the winter storm activity and by the sedimentary regime (predominantly erosive) of the area that did not allow the accumulation of appreciable quantities of fine material in the depressions. 
The variability in the composition and structure of the macrozoobenthic communities at the reference station, throughout the different surveys makes it difficult to analyze the recovery of the benthic community. A number of studies have highlighted the considerable intra- and inter-annual variability in composition and density of the community of sandy and muddy bottoms of the Northern Adriatic (Ambrogi et al., 1990; Bonvicini Pagliai et al., 1996; Bonvicini Pagliai et al., 1999; Prevedelli et al., 2001; Occhipinti Ambrogi et al., 2002; Simonini et al. 2004). It is likely that the fluctuations in density observed during the different surveys are linked to the biological cycles of different species and to the high seasonal variation in physical conditions in the Northern Adriatic Sea. For example, the reduction in terms of abundances and number of taxa that was observed during the A-Ex 12 survey can be related to the anomalous low temperature of the water $\left(4^{\circ} \mathrm{C}\right.$ in the bottom $)$ that occurred in the northern Adriatic sea during the winter 2002 and caused the mortality of several benthic species (Gismondi e Rinaldi, 2002).

The temporal variability among the surveys was low and could not be attributed to the impact of the extraction activity. The effects of sand extraction on the macrozoobenthic communities were particularly intense, especially during and immediately after the extraction at station 3 and 4 , and were mainly due to the removal of fauna from the seabed. The recolonisation at the impacted station began early by larval settlement (most polychaetes, molluscs, echinoderms and other sedentary organisms) and adult migration (vagile taxa, such as the dominant crustaceans A. latreilli and A. diadema). In other cases larval settlements were noted 
to have been the most important source of new recruits, rather than the migration of adults from nearby (Boyd \& Rees, 2003).

In contrast to the MDS and dissimilarity analyses, the high $\mathrm{R}$ value derived from the pair-wise ANOSIM test suggested that the community at the A-Ex impacted station were different from those found prior to the dredging operation, even 30 months after sand extraction. We suggest that the failure of the $\mathrm{R}$ statistic in detecting the recovery of the community could be the result of the low (spatial) variability among stations for each sampling survey relative to the natural seasonal and inter-annual variability of the benthic communities.

The $\%$ dissimilarity between Before-Extraction and After-Extraction impacted station decreased of over time and, starting from 18 month after dredging, the community of impacted station grouped together with the reference station and B-Ex station on one side of the MDS plots. These finding suggested that starting from 24 months after dredging the composition and structure of the macrozoobenthic assemblages becomes similar to that observed prior to sand extraction. In particular, the difference in the community of the B-Ex and the A-Ex 30 impacted stations are due to 1) some rare species exclusive to the first or the last survey; and 2) differences in the abundances of common species, characteristic of the relict sands biocoenosis, that can be related to the natural temporal variability of the communities. The species in common between the two surveys constituted about $90 \%$ of the whole abundances at both BEx and the A-Ex 30 impacted stations. Therefore it could be assumed that the communities of the dredged area returned to the original condition 30 months after sand extraction. 
This pattern of recolonisation-recovery fits well with the commonly encountered scenario where the substratum merely remains unchanged after marine aggregate excavation (Boyd et al., 2003, 2005; ICES, 2000). In most of these cases, the extraction area exhibited a strong hydrodynamic activity, which could obstruct the deposition of fine sediment, or the depth of the extraction was low, so the change in sediment structure of the dredged areas was limited over time and the complete recovery of the communities required a period of between 2 and 4 years.

In order to contrast coastal erosion along the Mediterranean coasts, the local governments and the environmental protection agencies of several regions and countries are planning new nourishment operations exploiting the relict sands (see INTEREG IIIC-BEACHMED project at http://www.beachmed.it). This monitoring programme has provided the opportunity to derive useful information for the evaluation of the consequences of relict sand extraction over sufficiently long time scales, from impact to recovery. Firstly, in order to separate the effects of sand extraction from the effects of the high inter- and intra-annual variability, the monitoring survey must be repeated a number of times both before and after dredging (Underwood, 1994). And secondly, to evaluate the outcome of the recolonisationrecovery processes the post-dredging survey might be performed 2-3 years after sand extraction

\section{Acknowledgements}


The Authors thank the crew of the oceanographic M/S "Daphne II" (Struttura Oceanografica Daphne, ARPA Emilia-Romagna), Mr. Marco Papperini and Mr. Dino Pagan, Dr M. Gabellini and his staff (ICRAM, Rome) for the coordination of the different monitoring activities, and Dr. Katie Henry for English language corrections. The research was financially supported by the Emilia-Romagna Region Project "Programma pluriennale di monitoraggio dell' area a mare da cui sono state prelevate le sabbie per il ripascimento delle spiagge emiliano-romagnole" ("Multiannual monitoring program of the offshore area of sand extraction for the nourishment of the Emilia-Romagna beaches", convention between ARPA Ingegneria Ambientale and Dipartimento di Biologia Animale, Università degli studi di Modena e Reggio Emilia).

\section{References}

Boyd, S.E., Limpenny, D.S., Rees, H.L., Cooper, K.M., \& Campbell, S. (2003). Preliminary observations of the effects of dredging intensity on the recolonization of dredged sediments off the south-east coast of England (Area 222). Estuarine \& Coastal Shelf Science, 57, 209-223.

Boyd, S.E., Limpenny, D.S., Rees, H.L., \& Cooper, K.M. (2005). The effects of marine sand and gravel extraction on the macrobenthos at a commercial dredging site (results 6 years post-dredging). ICES Journal of Marine Science, 62, 145-162. 
Boyd, S.E., \& Rees, H.L. (2003). An examination of the spatial scale of impact on the marine benthos arising from marine aggregate extraction in the central English Channel. Estuarine \& Coastal Shelf Science, 57, 1-16.

Clarke, K.R., \& Warwick, R.M. (2001). Change in marine communities: an approach to statistical analysis and interpretation. 2nd edition, Primer-E, Plymouth, UK.

ICES (2000). Section 16 of the ACME Report 2000 - Meeting of the Biodiversity Committee (BDC), Vlissingen.

ICRAM (2001). Intervento di messa in sicurezza dei tratti critici del litorale emiliano romagnolo mediante ripascimento con sabbie sottomarine: caratterizzazione dell'area di prelievo in mare. Relazione preliminare. ICRAM, Roma.

Kenny, A.J., \& Rees, H.L. (1994). The effects of marine gravel extraction on the macrobenthos; early post-dredging recolonisation. Marine Pollution Bulletin, $28(7), 442-447$.

Kenny, A.J., \& Rees, H.L. (1996). The effects of marine gravel extraction on the macrobenthos. Results 2 years post-dredging. Marine Pollution Bulletin, 32, 615622.

Kenny, A.J., Rees, H.L., Greening, J., \& Campbell, S. (1998). The effects of gravel extraction on the macrobenthos at an experimental dredge site off North Norfolk, UK (results 3 years post-dredging). ICES CM1998/V 14, 1-7.

Matteucci, M., \& Frascari, F. (1997). Fluxes of suspended materials in the north Adriatic sea (po prodelta area). Water, Air and Soil Pollution, 99, 557-572. 
Montanari, M. \& Pinardi, N. (2006). The currents of Emilia-Romagna coastal strip during the period 1995-2002. Quaderni di Arpa, Arpa Linea Editoriale, Bologna, Italy.

Newell, R.C., Seiderer, L.J., \& Hitchcock, D.R. (1998). The impact of dredging work in coastal waters: a review of the sensitivity to disturbance and subsequent recovery of biological resources on the sea bed. Oceanography and Marine Biology Annual Review, 36, 127-178.

North Sea Foundation (2005). Ecological effects of sand extraction in the North Sea. www.noordzee.nl/waterkwaliteit/ecological_effects.pdf.

Preti, M. (2000). Ripascimento di spiagge con sabbie sottomarine in EmiliaRomagna. Studi costieri, 5, 107-134.

Preti, M. (2002) Stato del litorale emiliano-romagnolo all'anno 2002. Quaderni di Arpa, Arpa Linea Editoriale, Bologna, Italy.

Robinson, J.E., Newell, R.C., Seiderer, L.J. \& Simpson, N.M. (2005). Impacts of aggregate dredging on sediment composition and associated benthic fauna at an offshore dredge site in the southern North Sea. Marine Environmental Research, $60,51-68$.

Sardà, R., Pinedo, S., Gremare, A., \& Taboada, S. (2000). Changes in the dynamics of shallow sandy bottoms assemblages due to sand extraction in the Catalan Western Mediterranean Sea. ICES Journal of Marine Science, 57, 1446-1453.

Simonini, R., Ansaloni, I., Bonvicini Pagliai, A.M., Cavallini, F., Iotti, M., Mauri, M., Montanari, G., Preti, M., Rinaldi, A., \& Prevedelli, D. (2005). The effects of sand 
extraction on the macrobenthos of a relict sands area (northern Adriatic Sea): results 12 months post-extraction. Marine Pollution Bulletin, 50, 768-777.

Underwood, A.J., 1994. On beyond BACI: sampling designs that might reliably detect environmental disturbances. Ecological Application, 4, 3-15.

Van der Veer, H.W., Bergman, M.J.N., \& Beukema, J.J. (1985). Dredging activities in the Dutch Wadden Sea: effects on macrobenthic infauna. Netherlands Journal of Sea Research, 19, 183-190.

Van Dalfsen, J.A., Essink, K., Toxvig Madsen, H., Birklund, J., Romero, J., \& Manzanera, M. (2000). Differential responses of macrozoobenthos to marine sand extraction in the North Sea and the Western Mediterranean. ICES Journal of Marine Science, 57, 1439-1445.

Van Dalfsen, J.A., \& Essink, K. (1997). Risk analysis of coastal nourishment techniques in the Netherlands (RIACON). National Institute for Coastal and Marine Management/RIKZ.

Whang, X.H., \& Pinardi N. (2003). Modeling the dynamics of sediment transport and resuspension in the northern Adriatic Sea. Journal Of Geophysical Research, 107, $1-23$. 
Table 1. Results of two-way ANOSIM for the effects of sand extraction at different surveys, performed on untrasformed and $4^{\text {th }}$ root transformed macrofaunal abundance data.

\begin{tabular}{cccrrr}
\hline Transformation & \multicolumn{2}{c}{ none } & & \multicolumn{2}{c}{$4^{\text {th }}$} \\
\cline { 2 - 3 } \cline { 5 - 6 } Statistics & $\mathrm{R}$ & $\mathrm{P}$ & & $\mathrm{R}$ & $\mathrm{P}$ \\
\cline { 2 - 3 } \cline { 5 - 6 } \\
Factors & & & & 0.635 & $<0.001$ \\
Extraction & 0.532 & $<0.001$ & & 0.732 & $<0.001$ \\
Survey & 0.791 & $<0.001$ & & & 0.732 \\
\hline
\end{tabular}


Table 2. Pair-wise test (One-way ANOSIM, untransformed data) and $\%$ average dissimilarity between the impacted stations vs reference stations for each survey, the impacted station from the different surveys $v s$ the pre-dredging station (B-Ex Imp) and the reference stations of the different surveys. Significant $R$ values $(P<0.05)$ are reported in bold.

\begin{tabular}{|c|c|c|c|c|c|}
\hline Groups & $R$ & $\%$ dissimilarity & Groups & $R$ & \% dissimilarity \\
\hline A-Ex 30: Imp. $v s$ Ref. & 0.075 & 33.5 & A-Ex $30 v s$ A-Ex 24 & 0.841 & 41.3 \\
\hline A-Ex 24: Imp. vs Ref. & 0.460 & 40.6 & A-Ex 30 vs A-Ex 18 & 0.21 & 33.0 \\
\hline A-Ex 18: Imp. vs Ref. & 0.508 & 35.8 & A-Ex 30 vs A-Ex 12 & 1.000 & 78.1 \\
\hline A-Ex 12: Imp. vs Ref. & 0.611 & 57.2 & A-Ex 30 vs A-Ex 6 & 0.760 & 51.0 \\
\hline A-Ex 6: Imp. vs Ref. & 0.742 & 57.7 & A-Ex 30 vs A-Ex 1 & 1.000 & 61.0 \\
\hline A-Ex 1: Imp. vs Ref. & 0.948 & 83.0 & A-Ex $30 v s$ Ex & 1.000 & 59.1 \\
\hline Ex: Imp. $v s$ Ref. & 0.861 & 84.5 & A-Ex $30 v s$ B-Ex & 0.995 & 56.3 \\
\hline \multirow[t]{3}{*}{ B-Ex: Imp. $v s$ Ref. } & -0.136 & 40.0 & A-Ex 24 ss A-Ex 18 & 0.653 & 38.5 \\
\hline & & & A-Ex 24 ss A-Ex 12 & 1.000 & 79.4 \\
\hline & & & A-Ex 24 vs A-Ex 6 & 0.832 & 55.5 \\
\hline B-Ex Imp. vs Ex Imp. & 0.444 & 89.2 & A-Ex 24 vs A-Ex 1 & 1.000 & 61.7 \\
\hline B-Ex Imp. vs Ex 1 Imp. & 1.000 & 91.1 & A-Ex $24 v s$ Ex & 1.000 & 60.3 \\
\hline B-Ex Imp. vs Ex 6 Imp. & 0.850 & 65.8 & A-Ex $24 v s$ B-Ex & 1.000 & 57.8 \\
\hline B-Ex Imp. vs Ex 12 Imp. & 1.000 & 83.2 & A-Ex 18 vs A-Ex 12 & 1.000 & 78.0 \\
\hline B-Ex Imp. vs Ex 18 Imp. & 1.000 & 51.9 & A-Ex $18 v s$ A-Ex 6 & 0.715 & 46.2 \\
\hline B-Ex Imp. vs Ex 24 Imp. & 1.000 & 58.9 & A-Ex $18 v s$ A-Ex 1 & 1.000 & 59.0 \\
\hline \multirow[t]{12}{*}{ B-Ex Imp. vs Ex 30 Imp. } & 000 & & A-Ex $18 v s$ Ex & 1.000 & 56.7 \\
\hline & & & A-Ex $18 v s$ B-Ex & 0.998 & 53.0 \\
\hline & & & A-Ex 12 vs A-Ex 6 & 0.949 & 72.1 \\
\hline & & & A-Ex 12 vs A-Ex 1 & 0.922 & 64.3 \\
\hline & & & A-Ex $12 v s$ Ex & 0.962 & 67.2 \\
\hline & & & A-Ex $12 v s$ B-Ex & 0.988 & 75.8 \\
\hline & & & A-Ex 6 vs A-Ex 1 & 0.741 & 50.7 \\
\hline & & & A-Ex $6 v s$ Ex & 0.771 & 53.1 \\
\hline & & & A-Ex $6 v s$ B-Ex & 0.631 & 48.6 \\
\hline & & & A-Ex $1 v s$ Ex & 0.896 & 49.3 \\
\hline & & & A-Ex $1 v s$ B-Ex & 0.963 & 53.8 \\
\hline & & & Ex $v s \mathrm{~B}-\mathrm{Ex}$ & 0.954 & 53.1 \\
\hline
\end{tabular}


Table 3. Pair-wise test (One-way ANOSIM, $4^{\text {th }}$ root transformed data) and $\%$ average dissimilarity between the impacted stations $v s$ reference ones of each survey, the impacted station from the different surveys $v s$ the pre-dredging station (B-Ex Imp) and the reference stations of the different surveys. Significant $R$ values $(P<0.05)$ are reported in bold.

\begin{tabular}{|c|c|c|c|c|c|}
\hline Groups & $R$ & $\%$ dissimilarity & Groups & $R$ & $\%$ dissimilarity \\
\hline A-Ex 30: Imp, $v s$ Ref, & 0,046 & 22.7 & A-Ex $30 v s$ A-Ex 24 & 1.000 & 29.8 \\
\hline A-Ex 24: Imp, vs Ref, & 0,698 & 27.7 & A-Ex $30 v s$ A-Ex 18 & 0.697 & 25.0 \\
\hline A-Ex 18: Imp, vs Ref, & 0,690 & 27.8 & A-Ex $30 v s$ A-Ex 12 & 0.857 & 57.1 \\
\hline A-Ex 12: Imp, $v s$ Ref, & 0,683 & 56.1 & A-Ex $30 v s$ A-Ex 6 & 0.890 & 37.6 \\
\hline A-Ex 6: Imp, vs Ref, & 0,651 & 37.9 & A-Ex $30 v s$ A-Ex 1 & 1.000 & 41.7 \\
\hline A-Ex 1: Imp, vs Ref, & 0,917 & 68.2 & A-Ex $30 v s$ Ex & 1.000 & 39.2 \\
\hline Ex: Imp, $v s$ Ref, & $\mathbf{0 , 8 4 9}$ & 72.8 & A-Ex $30 v s$ B-Ex & 0.996 & 39.0 \\
\hline \multirow[t]{3}{*}{ B-Ex: Imp, vs Ref, } & \multirow[t]{3}{*}{$-0,062$} & \multirow[t]{3}{*}{32.2} & A-Ex 24 ss A-Ex 18 & 0.974 & 29.7 \\
\hline & & & A-Ex 24 vs A-Ex 12 & 0.992 & 59.0 \\
\hline & & & A-Ex 24 vs A-Ex 6 & 0.983 & 41.5 \\
\hline B-Ex Imp. $v s$ Ex Imp. & 0.444 & 74.1 & A-Ex $24 v s$ A-Ex 1 & 1.000 & 42.7 \\
\hline B-Ex Imp. vs Ex 1 Imp. & 0.815 & 74.3 & A-Ex $24 v s$ Ex & 1.000 & 41.0 \\
\hline B-Ex Imp. vs Ex 6 Imp. & 0.815 & 45.5 & A-Ex $24 v s$ B-Ex & 1.000 & 41.6 \\
\hline B-Ex Imp. vs Ex 12 Imp. & 0.963 & 65.6 & A-Ex 18 vs A-Ex 12 & 0.863 & 57.0 \\
\hline B-Ex Imp. $v s$ Ex 18 Imp. & 1.000 & 39.1 & A-Ex $18 v s$ A-Ex 6 & 0.688 & 34.7 \\
\hline B-Ex Imp. $v s$ Ex 24 Imp. & 1.000 & 40.5 & A-Ex $18 v s$ A-Ex 1 & 1.000 & 41.4 \\
\hline \multirow[t]{12}{*}{ B-Ex Imp. vs Ex 30 Imp. } & \multirow[t]{12}{*}{1.000} & & A-Ex $18 v s$ Ex & 1.000 & 38.2 \\
\hline & & & A-Ex $18 v s$ B-Ex & 0.992 & 37.8 \\
\hline & & & A-Ex $12 v s$ A-Ex 6 & 0.734 & 52.6 \\
\hline & & & A-Ex $12 v s$ A-Ex 1 & 0.688 & 50.8 \\
\hline & & & A-Ex $12 v s$ Ex & 0.715 & 51.5 \\
\hline & & & A-Ex $12 v s$ B-Ex & 0.729 & 53.2 \\
\hline & & & A-Ex 6 vs A-Ex 1 & 0.793 & 35.1 \\
\hline & & & A-Ex $6 v s$ Ex & 0.741 & 34.4 \\
\hline & & & A-Ex $6 v s$ B-Ex & 0.642 & 33.8 \\
\hline & & & A-Ex $1 v s$ Ex & 0.773 & 32.9 \\
\hline & & & A-Ex $1 v s$ B-Ex & 0.821 & 34.3 \\
\hline & & & Ex $v s \mathrm{~B}-\mathrm{Ex}$ & 0.704 & 32.2 \\
\hline
\end{tabular}


Table 4. Number of taxa, density and Shannon diversity index calculated at each station of the different survey.

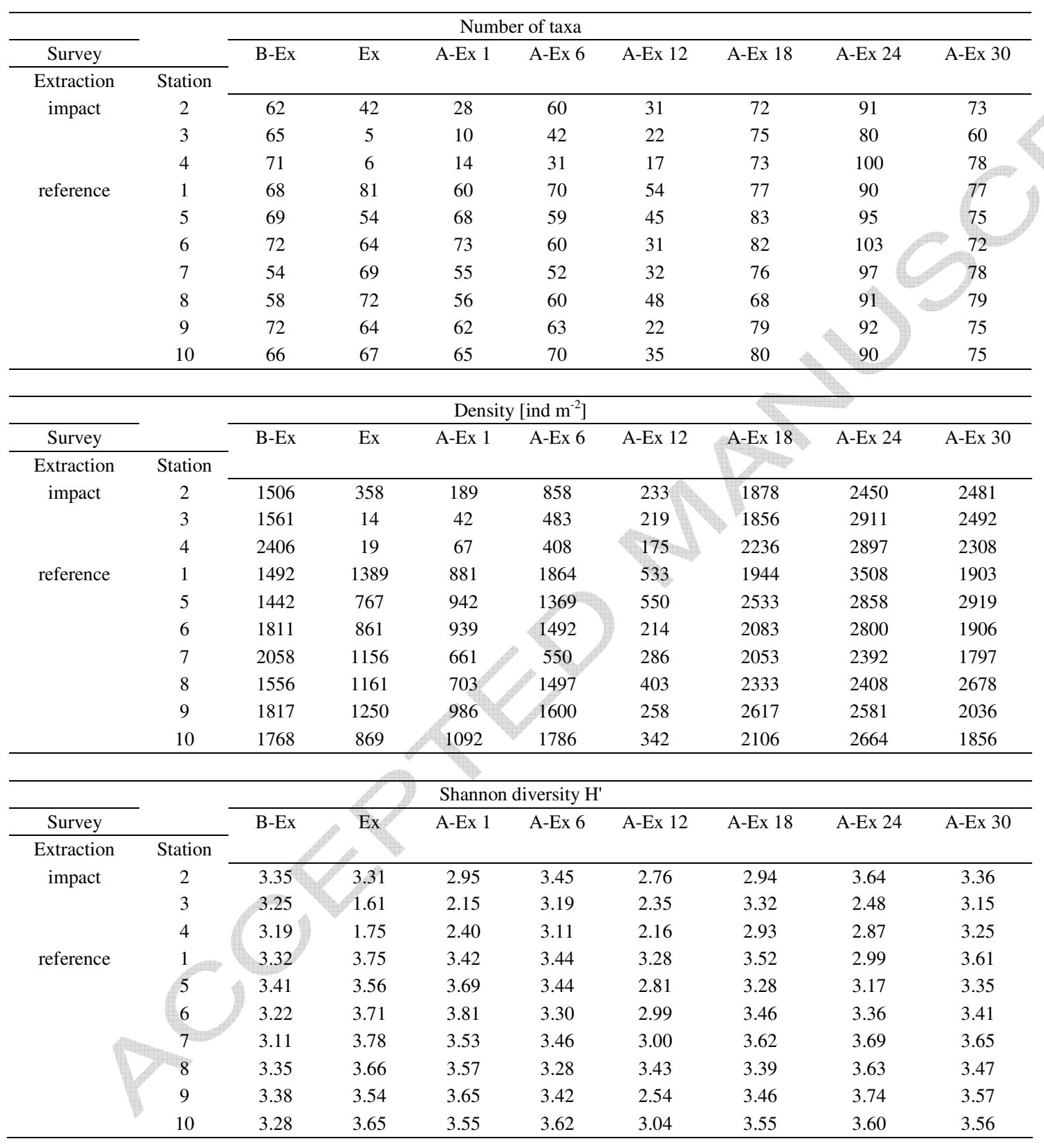




\section{Figure legend}

Fig. 1. Location of the sand extraction area with a map of the sampling stations and the sailing tracks of the dredger. Grey area $=$ sand extraction area; grey points $=$ stations in extraction area; white points= reference stations. The effects on the bottom profile was examined by side-scan sonar along the A-B axis.

Fig. 2. Grain size, and $\%$ total organic carbon (TOC; mean \pm 2 S.D.) at impacted and reference stations at each survey.

Fig. 3. Reconstruction of the bottom profile immediately after (A Ex 1 survey) and 24 months (A Ex 24 survey) after sand extraction (based on multi-beam data).

Fig. 4. 2D-nMDS ordination of: a) impacted (Imp) and reference (Ref) station at all surveys, untransformed abundance data; b) impacted and reference station at all surveys, $4^{\text {th }}$ root transformed abundance data; c) only impacted station at all surveys, untransformed abundance data; d) only impacted station at all surveys, $4^{\text {th }}$ root transformed abundance data; e) only reference station at all surveys, untransformed abundance data; f) only reference station at all surveys, $4^{\text {th }}$ root transformed abundance data. Abbreviations: B Ex - Before extraction; A Ex - After extraction followed by the time in months $(1,6,12,18,24$ and 30 months).

Fig. 5. Number of taxa, total abundance and Shannon-Wiener diversity index (mean \pm 2 S.D.) at impacted and reference stations of each survey. 


\section{ACCEPTED MANUSCRIPT}

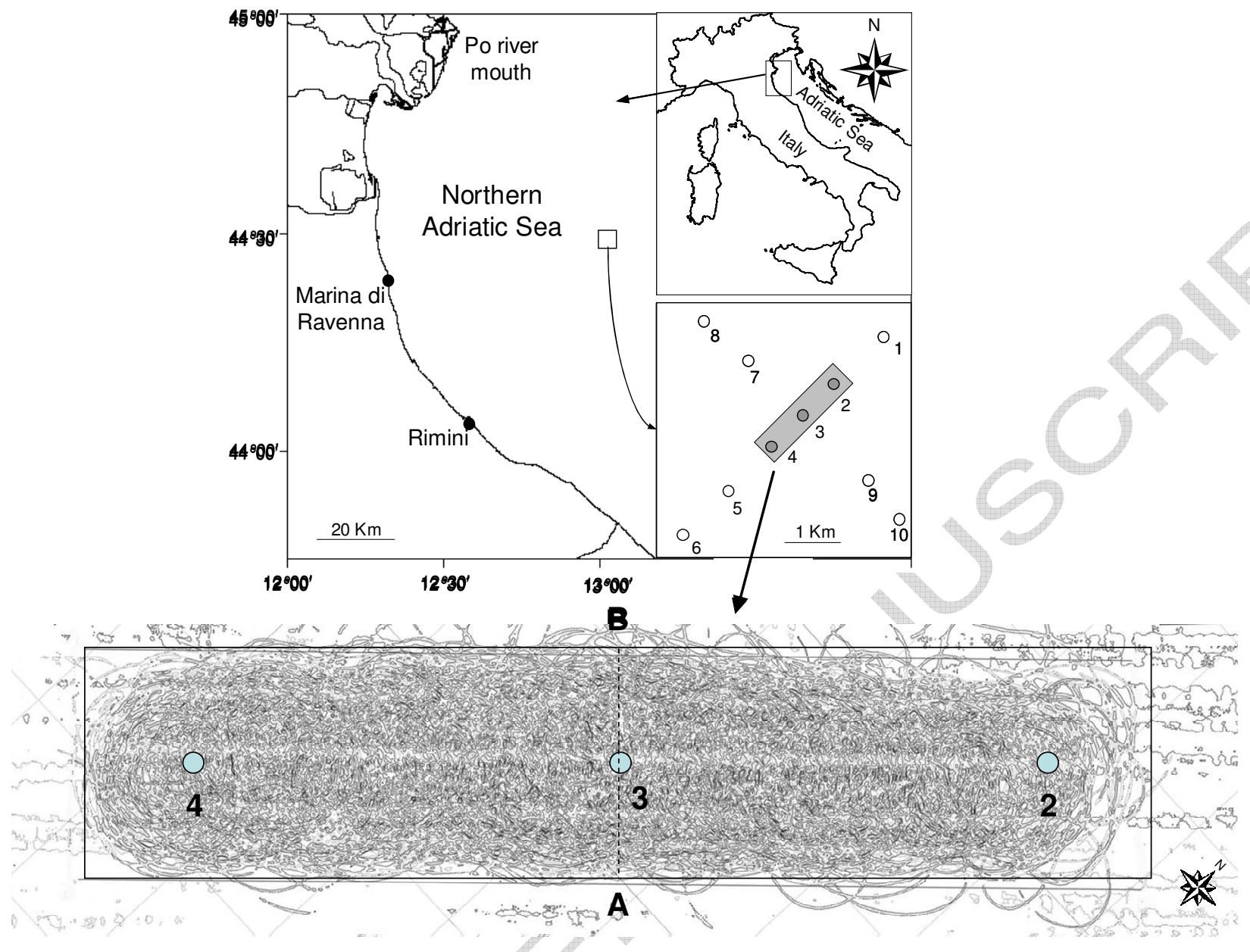

FIGURE 1 Simonini et al. 


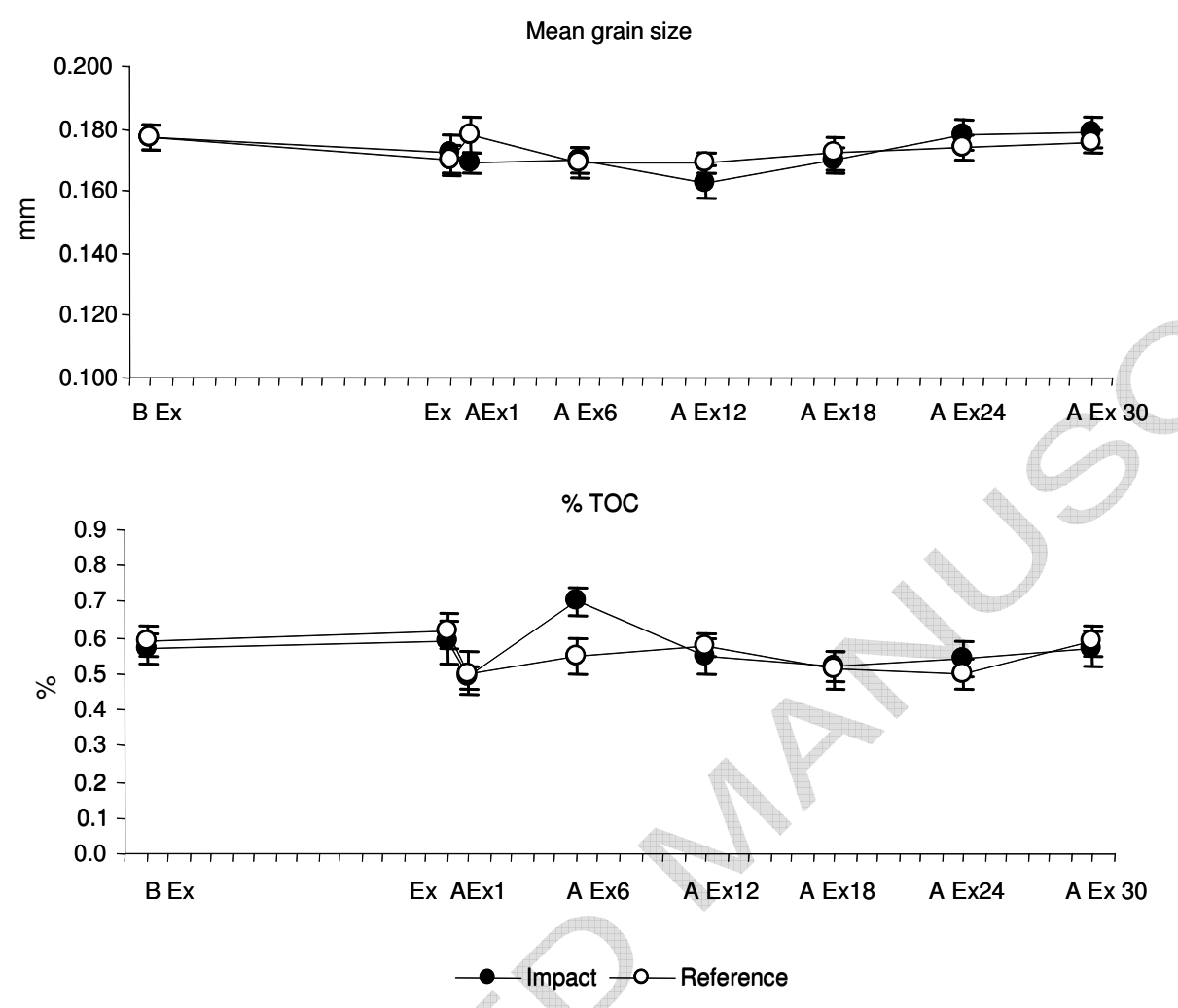

Fig. 2 Simonini et al. 


\section{ACCEPTED MANUSCRIPT}

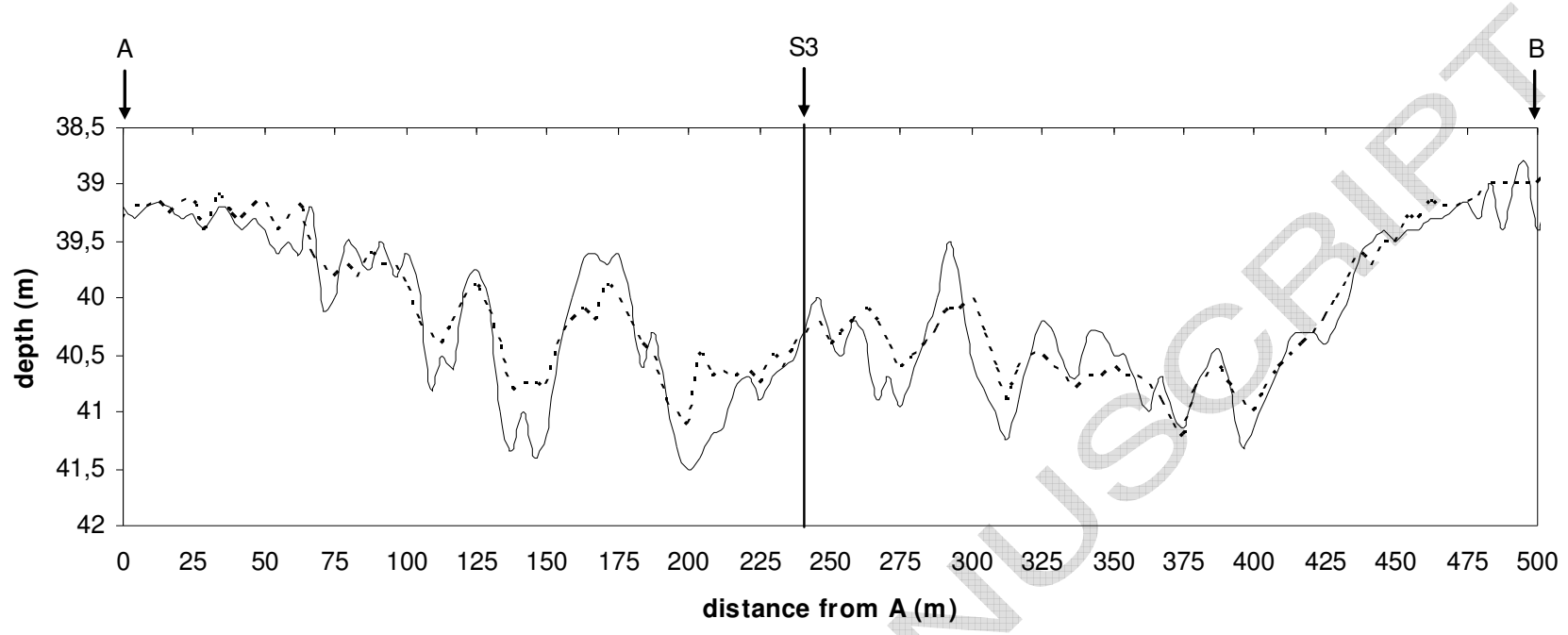

Fig. 3 Simonini et al. 


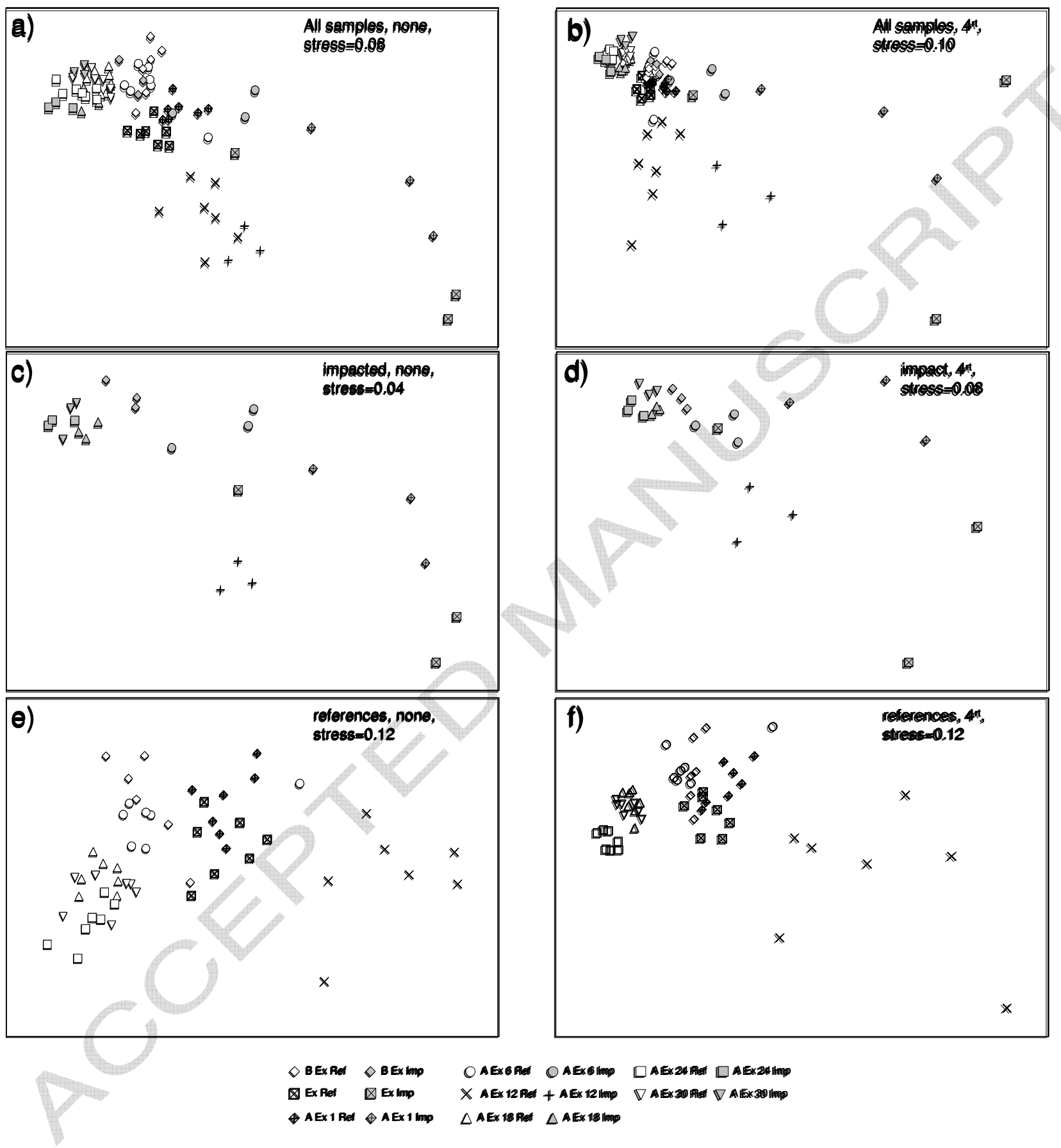

Fig. 4 Simonini et al. 

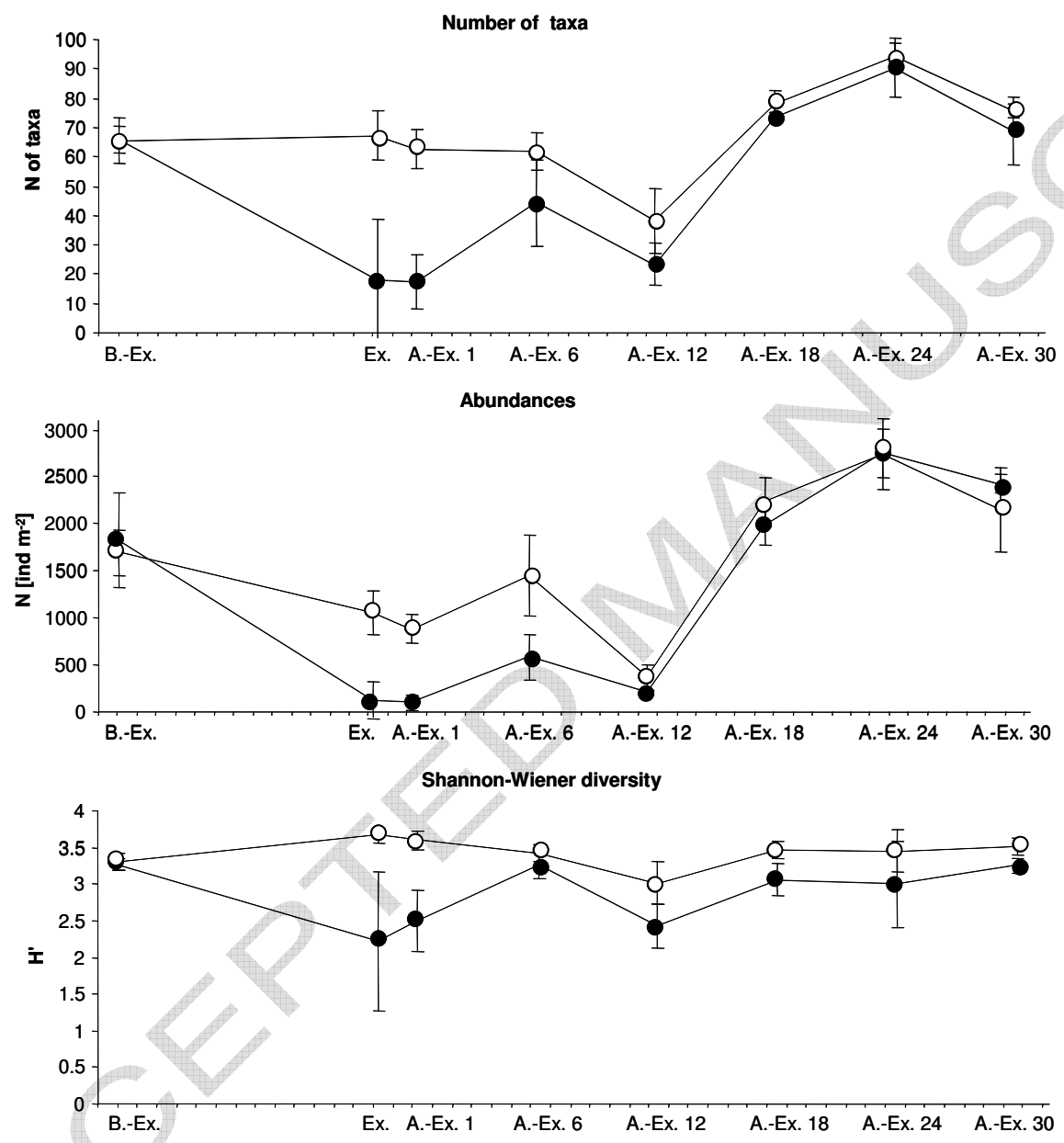

FIGURE 5 Simonini et al. 
Appendix 1. List of the taxa found during the eight surveys. Class $(\mathrm{Cl}$.$) : \mathrm{A}=$ amphipods; $\mathrm{An}=$ anthozoans; $\mathrm{Ap}=$ aplacophorans; As=ascidians; $\mathrm{B}=$ bivalves; $\mathrm{C}=$ cumaceans; $\mathrm{D}=$ decapods; $\mathrm{De}=$ demosponges; $\mathrm{E}=$ Echinoids; $\mathrm{Ec}=$ Echiurids; En= enteropneust; $\mathrm{G}=$ gastropods; $\mathrm{H}=$ hydrozoans; $\mathrm{Ho}=$ holothurians; $\mathrm{I}=$ isopods; $\mathrm{N}=$ nemerteans; $\mathrm{O}=$ ostracods; $\mathrm{Op}=$ ophiurans; $\mathrm{P}=$ Polychaetes; $\mathrm{Ph}=$ phoronids; $\mathrm{Po}=$ polyplacophorans; $\mathrm{S}=$ stomatopods; $\mathrm{Si}=$ sipunculids; $\mathrm{ST}=$ sea stars; $\mathrm{Sy}=$ sylicosponges; $\mathrm{T}=$ tanaidaceans.

\begin{tabular}{|c|c|c|c|c|c|}
\hline Taxon & $\mathrm{Cl}$. & Taxon & $\mathrm{Cl}$. & Taxon & $\mathrm{Cl}$. \\
\hline Amage adspersa & $\mathrm{P}$ & Prionospio cirrifera & $P$ & Holothuria forskali & Ho \\
\hline Ampharete acutifrons & $\mathrm{P}$ & Prionospio malmgreni & $P$ & Labidoplax digitata & Ho \\
\hline Aonides oxycephala & $\mathrm{P}$ & Prionospio steenstrupi & $\mathrm{P}$ & Leptosynapta inhaerens & Ho \\
\hline Aphelochaeta marioni & $\mathrm{P}$ & Protodorvillea atlantica & $\mathrm{P}$ & Ophiothrix fragilis & Op \\
\hline Aphelochaeta multibranchiis & $\mathrm{P}$ & Sabella pavonina & $P$ & Ophiura albida & $\mathrm{Op}$ \\
\hline Aphrodita aculeata & $\mathrm{P}$ & Sabellaria spinulosa & $P$ & Phyllophorus urna & Ho \\
\hline Aponuphis brementi & $\mathrm{P}$ & Sabellides octocirrata & $P$ & Schizaster canaliferus & $\mathrm{E}$ \\
\hline Aricidea claudiae & $\mathrm{P}$ & Scalibregma inflatum & $\mathrm{P}$ & Trachythyone elongata & Ho \\
\hline Armandia cirrhosa & $\mathrm{P}$ & Scolelepis cantabra & $\mathrm{P}$ & Maxmuelleria gigas & $\mathrm{Ec}$ \\
\hline Axionice maculata & $\mathrm{P}$ & Sigambra tentaculata & $P$ & Glossobalanus minutus & En \\
\hline Branchiomma lucullanum & $\mathrm{P}$ & Sphaerosyllis bulbosa & $P$ & Abra prismatica & B \\
\hline Dasybranchus caducus & $\mathrm{P}$ & Spio filicornis & $P$ & Achantocardia tubercolata & $\mathrm{B}$ \\
\hline Ditrupa arietina & $\mathrm{P}$ & Spio multioculata & $P$ & Anomia ephippium & B \\
\hline Eteone flava & $\mathrm{P}$ & Spiophanes kroyeri kroyeri & $\mathrm{P}$ & Aporrhais pespelecani & G \\
\hline Euchone sp. & $\mathrm{P}$ & Sthenolepis yhleni & $P$ & Atrina pectinata & B \\
\hline Euclymene lumbricoides & $\mathrm{P}$ & Syllis amica & $\mathrm{P}$ & Azorinus chamasolen & B \\
\hline Euclymene oerstedii & $\mathrm{P}$ & Syllis cornuta & $\mathrm{P}$ & Calyptraea chinensis & $\mathrm{G}$ \\
\hline Eunice pennata & $\mathrm{P}$ & Tachytrypane jeffreysii & $\mathrm{P}$ & Chlamys varia & B \\
\hline Eunice vittata & $\mathrm{P}$ & Terebellides stroemi & $\mathrm{P}$ & Clausinella brongniartii & B \\
\hline Filogranula annulata & $\mathrm{P}$ & Thalenessa dendrolepis & $P$ & Corbula gibba & B \\
\hline Glycera alba & $\mathrm{P}$ & Acheus gracilis & $\mathrm{D}$ & Cuspidaria rostrata & B \\
\hline Glycera capitata & $\mathrm{P}$ & Ampelisca diadema & A & Cylichna cylindracea & $\mathrm{G}$ \\
\hline Glycera tridactyla & $\mathrm{P}$ & Apseudes latreillii & $\mathrm{T}$ & Dosinia lupinus & B \\
\hline Goniada maculata & $\mathrm{P}$ & Atelecyclus rotundatus & $\mathrm{D}$ & Ensis ensis & $\mathrm{B}$ \\
\hline Harmothoe imbricata & $\mathrm{P}$ & Bodotria scorpioides & $\mathrm{C}$ & Fusinus rostratus & G \\
\hline Harmothoe johnstoni & $\mathrm{P}$ & Callianassa subterranea & $\mathrm{D}$ & Glycymeris insubrica & $\mathrm{B}$ \\
\hline Harmothoe lunulata & $\mathrm{P}$ & Cirolana borealis & I & Hiatella rugosa & $\mathrm{B}$ \\
\hline Hydroides norvegicus & $\mathrm{P}$ & Corystes cassivelaunus & $\mathrm{D}$ & Hyala vitrea & G \\
\hline Jasmineira elegans & $\mathrm{P}$ & Diastylis rugosa & $\mathrm{C}$ & Hyalopecten similis & $\mathrm{B}$ \\
\hline Kefersteinia cirrata & $\mathrm{P}$ & Ebalia deshayesi & $\mathrm{D}$ & Lentidium mediterraneum & B \\
\hline Lanice conchylega & $\mathrm{P}$ & Ethusa mascarone & D & Lepidopleurus cancellatus & Po \\
\hline Laonice cirrata & $\mathrm{P}$ & Galathea intermedia & D & Loripes lacteus & $\mathrm{B}$ \\
\hline Lepidonotus clava & $\mathrm{P}$ & Gammaridae n.c. & A & Lucinella divaricata & B \\
\hline Lumbrineris latreilli & $\mathrm{P}$ & Gnathia phallonajopsis & $\mathrm{I}$ & Mactra stultorum & $\mathrm{B}$ \\
\hline Lumbrineris tetraura & $\mathrm{P}$ & Inachus dorsettensis & D & Melanella polita & G \\
\hline Magelona papillicornis & $\mathrm{P}$ & Iphinoe tenella & $\mathrm{C}$ & Modiolarca subpicta & $\mathrm{B}$ \\
\hline Malacoceros girardi & $\mathrm{P}$ & Leptognathia brevimanu & $\mathrm{T}$ & Modiolula phaseolina & B \\
\hline Maldane sarsi & $\mathrm{P}$ & Liocarcinus arcuatus & $\mathrm{D}$ & Myrtea spinifera & $\mathrm{B}$ \\
\hline Marphysa bellii & $\mathrm{P}$ & Nannastacidae n.d. & $\mathrm{C}$ & Mysella bidentata & $\mathrm{B}$ \\
\hline Melinna palmata & $\mathrm{P}$ & Ostracoda n.c. & $\mathrm{O}$ & Nucula nitidosa & B \\
\hline Micronephtys sphaerocirrata & $\mathrm{P}$ & Pagurus anachoretus & $\mathrm{D}$ & Nuculana pella & $\mathrm{B}$ \\
\hline Monticellina dorsobranchialis & $\mathrm{P}$ & Philocheras sculptus & $\mathrm{D}$ & Paphia aurea & $\mathrm{B}$ \\
\hline Neanthes succinea & $\mathrm{P}$ & Phtisica marina & A & Parvicardium exiguum & B \\
\hline Nematonereis unicornis & $\mathrm{P}$ & Pilumnus hirtellus & $\mathrm{D}$ & Phaxas adriaticus & $\mathrm{B}$ \\
\hline Nephtys hombergii & $\mathrm{P}$ & Platysquilla eusebia & $S$ & Philine scabra & G \\
\hline Nothria conchylega & $\mathrm{P}$ & Processa canaliculata & $\mathrm{D}$ & Pitar rudis & $\mathrm{B}$ \\
\hline Notomastus latericeus & $P$ & Pycnogonida n.d. & Py & Polinices nitida & $\mathrm{G}$ \\
\hline Ophiodromus agilis & $\mathrm{P}$ & Rissoides desmaresti & $\mathrm{D}$ & Prochaetoderma raduliferum & Ap \\
\hline Orbinia cuvieri & $\mathrm{P}$ & Sicyonia carinata & $\mathrm{D}$ & Psammobia fervensis & $\mathrm{B}$ \\
\hline Owenia fusiformis & $\mathrm{P}$ & Solenocera mebranacea & $\mathrm{D}$ & Solemya togata & B \\
\hline Paraonides neapolitana & $\mathrm{P}$ & Upogebia pusilla & $\mathrm{D}$ & Tellimya ferruginosa & $\mathrm{B}$ \\
\hline Pectinaria auricoma & $\mathrm{P}$ & Ascidia involuta & As & Tellina distorta & $\mathrm{B}$ \\
\hline Pectinaria koreni & $\mathrm{P}$ & Alcyonium sp. & An & Thracia papyracea & $\mathrm{B}$ \\
\hline Pherusa plumosa & $\mathrm{P}$ & Anthozoa n.c. & An & Thyasira flexuosa & B \\
\hline Phyllodoce macrophthalma & $\mathrm{P}$ & Condylactis aurantiaca & An & Nemertea n.c. sp1 & $\mathrm{N}$ \\
\hline Pilargis verrucosa & $\mathrm{P}$ & Hydrozoa n.d. & $\mathrm{H}$ & Phoronis muelleri & $\mathrm{Ph}$ \\
\hline Pista cristata & $\mathrm{P}$ & Amphipholis squamata & Op & Sycon sp. & Sy \\
\hline Poecilochaetus fauchaldi & $\mathrm{P}$ & Amphiura chiajei & Op & Timeidae n.d. & $\mathrm{D}$ \\
\hline Polydora flava & $\mathrm{P}$ & Amphiura filiformis & Op & Aspidosiphon muelleri & $\mathrm{Si}$ \\
\hline Pomatoceros lamarckii & $\mathrm{P}$ & Astropecten irregularis & St & Phascolion strombi & $\mathrm{Si}$ \\
\hline Pomatoceros triqueter & $\mathrm{P}$ & Echinocyamus pusillus & $\mathrm{E}$ & Sipunculus nudus & $\mathrm{Si}$ \\
\hline
\end{tabular}


Appendix 2. Average abundance (ind $\mathrm{m}^{-2}$ ), $\%$ contribution and cumulative contribution of taxa which most contribute to within-group similarity and between-group dissimilarity between impacted (Imp) stations at before extraction (B Ex) and after 30 month extraction (A Ex 30) surveys (SIMPER).

\begin{tabular}{|c|c|c|c|c|c|c|c|c|}
\hline \multicolumn{9}{|c|}{ SIMPER (cut-off 50\%) no trasformation } \\
\hline Group & B Ex Imp & & & Groups & \\
\hline Average similarity & 71.32 & & & Average dissimilarity & \multicolumn{4}{|c|}{${ }_{54.28}^{\text {B Ex Imp vs A Ex } 30 \text { Imp }}$} \\
\hline Taxa & Av.Abund & Cont. \% & Cum. \% & Group & B Ex Imp & \multicolumn{3}{|l|}{ A Ex 30 Imp } \\
\hline Spiophanes kroyeri kroyeri & 261.1 & 17.2 & 17.2 & Taxa & Av.Abund & Av.Abund & Cont. $\%$ & Cum.\% \\
\hline Apseudes latreillii & 207.4 & 13.1 & 30.3 & Apseudes latreillii & 207.4 & 614.8 & 18.0 & 18.0 \\
\hline Gammaridae n.c. & 188.9 & 12.8 & 43.1 & Spiophanes kroyeri kroyeri & 261.1 & 7.4 & 11.0 & 29.0 \\
\hline Aricidea claudiae & 238.0 & 9.8 & 52.9 & Aricidea claudiae & 238.0 & 129.6 & 6.3 & 35.3 \\
\hline & \multirow{3}{*}{\multicolumn{3}{|c|}{$\begin{array}{l}\text { A Ex } 30 \mathrm{Imp} \\
69.53\end{array}$}} & Gammaridae n.c. & 188.9 & 75.9 & 4.9 & 40.1 \\
\hline Group & & & & Aphelochaeta marioni & 43.5 & 119.4 & 4.1 & 44.3 \\
\hline Average similarity & & & & Magelona papillicornis & 3.7 & 85.2 & 3.6 & 47.9 \\
\hline Taxa & Av.Abund & Cont. $\%$ & Cum.\% & Jasmineira elegans & 38.9 & 106.5 & 3.0 & 50.9 \\
\hline Apseudes latreillii & 614.8 & 34.8 & 34.8 & & & & & \\
\hline Jasmineira elegans & 106.5 & 5.3 & 40.1 & & & & & \\
\hline Paraonides neapolitana & 100.9 & 4.6 & 44.7 & & & & & \\
\hline Magelona papillicornis & 85.2 & 4.1 & 48.7 & & & & & \\
\hline Aricidea claudiae & 129.6 & 4.0 & 52.7 & & & & & \\
\hline \multicolumn{9}{|c|}{ SIMPER (cut-off 50\%) 4rt root trasformation } \\
\hline Group & B Ex Imp & & & Groups & \multicolumn{4}{|c|}{ B Ex Imp vs A Ex 30 Imp } \\
\hline Average similarity & 75.45 & & & Average dissimilarity & 40.27 & & & \\
\hline Taxa & Av.Abund & Cont. $\%$ & Cum. $\%$ & Group & \multicolumn{4}{|c|}{ B Ex Imp A Ex 30 Imp } \\
\hline Spiophanes kroyeri kroyeri & 261.1 & 4.1 & 4.1 & Taxa & Av.Abund & Av.Abund & Cont. $\%$ & Cum.\% \\
\hline Apseudes latreillii & 207.4 & 3.8 & 7.8 & Magelona papillicornis & 3.7 & 85.2 & 2.3 & 2.3 \\
\hline Aricidea claudiae & 238.0 & 3.5 & 11.4 & Spiophanes kroyeri kroyeri & 261.1 & 7.4 & 2.2 & 4.5 \\
\hline Gammaridae n.c. & 188.9 & 3.5 & 14.9 & Prionospio malmgreni & 0.0 & 32.4 & 2.0 & 6.5 \\
\hline Aponuphis brementi & 77.8 & 3.0 & 17.9 & Callianassa subterranea & 0.0 & 24.1 & 2.0 & 8.5 \\
\hline Paraonides neapolitana & 55.6 & 2.8 & 20.7 & Malacoceros girardi & 15.8 & 0.0 & 1.8 & 10.3 \\
\hline Ampelisca diadema & 58.3 & 2.7 & 23.4 & Eunice pennata & 16.7 & 0.0 & 1.8 & 12.1 \\
\hline Lumbrineris latreilli & 49.1 & 2.7 & 26.1 & Ampharete acutifrons & 0.0 & 15.8 & 1.8 & 13.9 \\
\hline Aphelochaeta multibranchiis & 54.6 & 2.7 & 28.8 & Syllis cornuta & 0.0 & 12.0 & 1.7 & 15.6 \\
\hline Jasmineira elegans & 38.9 & 2.4 & 31.2 & Pectinaria koreni & 0.0 & 10.2 & 1.6 & 17.2 \\
\hline Aphelochaeta marioni & 43.5 & 2.3 & 33.5 & Eunice vittata & 0.0 & 9.3 & 1.5 & 18.8 \\
\hline Pista cristata & 19.4 & 2.2 & 35.6 & Solemya togata & 7.4 & 0.0 & 1.5 & 20.3 \\
\hline Eteone flava & 23.1 & 2.2 & 37.8 & Hydroides norvegicus & 0.0 & 7.4 & 1.5 & 21.8 \\
\hline Melinna palmata & 24.1 & 2.2 & 39.9 & Sabella pavonina & 0.0 & 6.5 & 1.5 & 23.2 \\
\hline Marphysa bellii & 25.0 & 2.1 & 42.0 & Nematonereis unicornis & 17.6 & 0.9 & 1.5 & 24.7 \\
\hline Notomastus latericeus & 15.8 & 2.1 & 44.1 & Marphysa bellii & 25.0 & 5.6 & 1.5 & 26.1 \\
\hline Sigambra tentaculata & 18.5 & 2.0 & 46.1 & Liocarcinus arcuatus & 0.0 & 5.6 & 1.4 & 27.5 \\
\hline Poecilochaetus fauchaldi & 22.2 & 2.0 & 48.1 & Ophiura albida & 6.5 & 50.9 & 1.4 & 28.9 \\
\hline \multirow[t]{2}{*}{ Malacoceros girardi } & 15.8 & 1.9 & 50.0 & Lumbrineris tetraura & 17.6 & 2.8 & 1.4 & 30.3 \\
\hline & \multicolumn{3}{|c|}{ 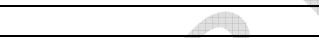 } & Nemertea n.c. & 4.6 & 34.3 & 1.3 & 31.6 \\
\hline Group & A Ex 30 & $\operatorname{Imp}$ & & Pagurus sp. & 0.9 & 10.2 & 1.3 & 32.9 \\
\hline Average similarity & 75.17 & & & Nephtys hombergii & 11.1 & 6.5 & 1.2 & 34.1 \\
\hline Taxa & Av.Abund & Cont. $\%$ & Cum. $\%$ & Glycera capitata & 8.3 & 0.9 & 1.2 & 35.2 \\
\hline Apseudes latreillii & 614.8 & 4.6 & 4.6 & Aponuphis brementi & 77.8 & 55.6 & 1.2 & 36.4 \\
\hline Jasmineira elegans & 106.5 & 2.9 & 7.5 & Phoronis muelleri & 1.9 & 10.2 & 1.2 & 37.6 \\
\hline Paraonides neapolitana & 100.9 & 2.8 & 10.3 & Nannastacidae n.d. & 0.9 & 8.3 & 1.2 & 38.8 \\
\hline Magelona papillicornis & 85.2 & 2.7 & 13.0 & Monticellina dorsobranchialis & 32.4 & 8.3 & 1.2 & 39.9 \\
\hline Aricidea claudiae & 129.6 & 2.7 & 15.7 & Schizaster canaliferus & 0.0 & 9.3 & 1.1 & 41.1 \\
\hline Ampelisca diadema & 83.3 & 2.6 & 18.3 & Apseudes latreillii & 207.4 & 614.8 & 1.1 & 42.2 \\
\hline Euchone sp. & 79.6 & 2.6 & 20.9 & Hydrozoa n.d. & 0.9 & 7.4 & 1.1 & 43.3 \\
\hline Aphelochaeta multibranchiis & 79.6 & 2.5 & 23.3 & Pomatoceros triqueter & 0.0 & 6.5 & 1.1 & 44.4 \\
\hline Poecilochaetus fauchaldi & 48.1 & 2.4 & 25.7 & Amage adspersa & 4.6 & 24.1 & 1.1 & 45.5 \\
\hline Ophiura albida & 50.9 & 2.3 & 28.0 & Phtisica marina & 3.7 & 22.2 & 1.1 & 46.6 \\
\hline Aphelochaeta marioni & 119.4 & 2.3 & 30.3 & Phaxas adriaticus & 0.9 & 8.3 & 1.1 & 47.7 \\
\hline Gammaridae n.c. & 75.9 & 2.5 & 32.7 & Diastylis rugosa & 0.0 & 5.6 & 1.1 & 48.8 \\
\hline Sigambra tentaculata & 39.8 & 2.2 & 34.9 & Micronephtys sphaerocirrata & 0.0 & 4.6 & 1.0 & 49.8 \\
\hline Nemertea n.c. & 34.3 & 2.1 & 37.0 & Orbinia cuvieri & 0.0 & 5.6 & 1.0 & 50.8 \\
\hline Lumbrineris latreilli & 32.4 & 2.1 & 39.1 & & & & & \\
\hline Goniada maculata & 31.5 & 2.1 & 41.2 & & & & & \\
\hline Cirolana borealis & 25.9 & 2.0 & 43.1 & & & & & \\
\hline Syllis amica & 50.9 & 1.9 & 45.1 & & & & & \\
\hline Phtisica marina & 22.2 & 1.9 & 47.0 & & & & & \\
\hline Amage adspersa & 24.1 & 1.9 & 48.9 & & & & & \\
\hline Leptognathia brevimanu & 15.8 & 1.8 & 50.6 & & & & & \\
\hline
\end{tabular}

